\title{
Effect of Fine Percentage on the Properties of Sub-base Material
}

\author{
I.I.I. Inan, W.K. Mampearachchi and P.A.S. Udayanga
}

\begin{abstract}
Finding sub-base material as per required specifications is a major issue in many parts of Sri Lanka. Therefore, in some cases, crushed stone is used as an alternative to sub-base material. Since good quality material is scarce, it is worthwhile to study the use of marginal materials to ensure sustainable development of the highway sector. The specification used in Sri Lanka for road constructions is the Standard Specification for Construction and Maintenance of Roads and Bridges (SCA/5) (SSCM) (ICTAD, 2009). Sub-base material is classified as lower sub-base material and upper sub-base material according to their Liquid Limit (LL), Plastic Limit (PL), Maximum Dry Density (MDD), California Bearing Ratio (CBR), and Sieve Analysis. A questionnaire survey was conducted among those engaged in the construction industry, to collect information on sub-base construction and on issues connected with the current specification relating to the passing percentage of the fine fraction. As a result, an experimental study was conducted by altering the fine fraction of soil from $0 \%$ to $40 \%$. It was also verified whether the grading band of No.200 sieve passing can be relaxed up to a certain percentage if the soil sample satisfies the specified CBR, Plasticity Index (PI) value and swell percentage requirement. It was found that the proposed changes have been adopted in AASHTO and Road Note 31 specifications. Furthermore, linear regression models were fitted to assess the CBR of material in relation to fine fractions (percentage passing of $425 \mu \mathrm{m}, 300 \mu \mathrm{m}, 75 \mu \mathrm{m}$ sieves). These passing percentages were identified as the most important percentages in predicting the CBR of the soil tested.
\end{abstract}

Keywords: $\quad$ Sub-base materials, Grading band, Fine fraction, CBR

\section{Introduction}

The road construction industry in Sri Lanka has grown rapidly during the last decade. The construction of new expressways, rehabilitation of main arterial roads and improvement of rural roads are taking place throughout the country and these activities collectively contribute to more than $10 \%$ of the government expenditure. The current trends in the construction industry have resulted in an increased demand on materials used for road construction. The Standard Specification for Construction and Maintenance of Roads and Bridges (SCA/5) (SSCM) published by the Institute for Construction Training and Development is being widely used in road construction in the country today [1]. The sources of the materials used have to comply with the Soil Conservation Act (No. 25 of 1951), Soil Conservation (Amendment) Act (No. 24 of 1996) and the Geological Survey and Mines Bureau Act (No. 33 of 1992). The important tests that are required for assessing the quality of any sample of soil are the Liquid Limit Test, Plastic Limit Test, Modified Proctor Compaction Test, California Bearing Ratio Test and Sieve Analysis Test.
The properties of a sub-base material can vary according to changes in its fine particle fractions. Therefore, it is vital to ascertain the correlation between sub-base material properties and the fine percentage.

\section{Objective}

This research aims at studying the importance of sub-base material properties and ascertaining whether any relaxation on the fine aggregate percentage is possible. The study is focused on identifying the effects of the fine percentage on sub-base material properties and on determining the correlation between the CBR and each of the important soil parameters.

Eng. I.I.I. Inan, C.Eng, MIE (Sri Lanka), B.Sc. Eng. (Hons), (Peradeniya), MEng.(Highway and Traffic), Executive Engineer (Maho), Road Development Authority. Email:irazinan@gmail.com

Eng. (Prof.) W.K. Mampearachchi, C.Eng, MIE(Sri Lanka), B.Sc. Eng (Moratuwa), MSCE (South Florida), Ph.D. (Florida),. Professor of Civil Engineering,

Department of Civil Engineering, University of Moratuwa. Email:wk.mampearachchi@gmail.com

Eng. P.A.S. Udayanga, AMIE(Sri Lanka), B.Sc. Eng. (Hons), (Moratuwa), Lecturer, Department of Civil

Engineering, University of Moratuwa.

Email:udayanga.sajith@yahoo.com 


\section{Literature Review}

\subsection{Classification of Soil}

Most soils consist of particles formed of both rock and organic material. Soil has to be classified according to its performance as done for other similar materials. It has to be tested for compactability, strength, stiffness, swell potential and permeability.

Major soil groups can be defined according to their gradations. Uniform soil is composed of particles of the same size which are often sands or heavy expansive clays. A well-graded range of particle sizes found in gradational soils makes the latter potentially useful in road construction work.

\subsubsection{Fine Grained Soil - Clays}

Clays can be classified by their particle type, expansion potential, behavior when hand molded and by its clay content. High plasticity indexes indicate the presence of clays in soil. Clays in arid to semi-arid areas and in cold climate areas with a plasticity index of more than $30 \%$ have a high potential for expansion. Similarly, clays in humid climate areas having a PI exceeding $50 \%$ also show a high potential for expansion [3].

\section{- Swelling and Expansion}

When ionized water gets attached to clay particles, the volume of absorbed water can be many times the actual volume of the clay particles. When water disappears, there would be consequential shrinkage and cracking. Clays can also swell when water entry reduces the high internal suction stresses [3].

The soil group 'Kaolin' is non-expansive, of low plasticity, less surface-active, and permeable. On the other hand, the soil group 'Illite' is expansive, has medium plasticity, is moderately surface-active and has low permeability. The soil group 'Smectiteis' is highly expansive, very plastic, very surfaceactive, and impermeable [4].

Swell potential expressed as a percentage can be defined as expansion divided by the original distance between two stone discs.

Materials in a pavement that swell by more than 2 percent when saturated can cause problems. Soil is called expansive if they swell by above 2.5 percent. However, the swelling of certain types of clays can be of the order of 20 percent and can lead to fissures in the soil during dry weather. If resisted, the expansion can create large swelling pressures (e.g. 100 $\mathrm{kPa}$ ) which can disrupt road surfaces, tilt poles, and even break utility pipes. Seasonal vertical movements (heaves) can be up to $65 \mathrm{~mm}$ which will have diminishing effects up to a depth of 2 $\mathrm{m}$. These volume changes can be minimized by preventing the changes in the moisture content [3].

One technique that can be applied in this regard is the compaction of the expansive clays in critical areas at their equilibrium moisture content, rather than at their Optimum Moisture Content (OMC). The expansive material can also be protected from moisture. A specific method in this regard is to cover the expansive material with an impermeable layer of nonswelling material. This capping layer should be at least $150 \mathrm{~mm}$ in thickness. Roots of roadside trees can particularly dry out soil. If both these techniques fail, it may become necessary to replace the expansive clays. Pre-wetting and the use of membranes to prevent moisture migration within the layer are the common techniques used in constructions on expansive clays [5].

\subsection{Soil Classification Systems}

\subsubsection{AASHTO Soil Classification}

The AASHTO classification system classifies soils into seven groups ranging from A-1 to A-7 each having several sub-groups. The classification of soil is based on its particle size distribution, LL, and PI. It is evaluated through the Group Index (GI) using the empirical formula given in Equation 1.

$$
\begin{aligned}
G I=(F-35)[0.2 & +0.005(L L-40)] \\
& +0.01(F-15)(P I-10)
\end{aligned}
$$

where

GI - Group Index as a whole number

$F$ - Percentage of soil particles passing through the $0.075 \mathrm{~mm}$ sieve as a whole number based on material passing through the $75 \mathrm{~mm}$ sieve

LL - Liquid limit as a whole number

PI - Plasticity Index as a whole number

The GI has to be a positive integer and its negative values are recorded as zeros. In addition, in determining the GI for A-2-6 and A-2-7 subgroups, the LL part of Equation 1 is ignored and only the second term of the equation is used. Generally, the rating for a pavement sub-grade or sub-base is inversely proportional to the Group Index. A GI value of zero is an indication of a good material. 
Material having a GI value of 20 can be considered as weak [6].

Granular soil falls into classes A-1 to A-3. A-1 soil consists of well-graded granular materials. A-2 soil contains significant amounts of silts and clays, and A-3 soil is clean but is formed of poorly graded sand. The soil classified as A-1-a, A-1-b, A-2-4, A-2-5, and A-3 can be used satisfactorily as sub-grade or sub-base material, provided it has got proper drainage $[7,6]$.

\subsubsection{USCS Soil Classification}

This system classifies coarse-grained soils based on their grain size characteristics and finegrained soils according to their plasticity characteristics. The USCS defines four major groups of materials, as coarse-grained soils, fine-grained soils, organic soils, and peat. Coarse-grained soils can be subdivided as Gravels (G) and Sands (S). Soil containing over 50 percent of particles larger than $75 \mathrm{~mm}$ in size that is, those retained in a No. 4 sieve, is gravel and that with more than 50 percent of its particles smaller than $75 \mathrm{~mm}$ in size which pass through a No. 4 sieve is sand.

Gravel and sand are further divided into four subgroups, each based on the grain-size distribution and the nature of their fine particles. Thus, they can be classified as wellgraded $(W)$, poorly graded $(P)$, silty $(M)$, or clayey (C). Gravel can be described as either well-graded gravel (GW), poorly graded gravel (GP), silty gravel (GM), or clayey gravel (GC) and similarly sand can be described as wellgraded sand (SW), poorly graded sand (SP), silty sand (SM), or clayey sand (SC) [2]. Previous studies have shown an approximate correlation between the AASHTO and the USCS [9].

\subsection{Correlations of CBR}

\subsubsection{Correlation with the Clay Content}

Both the clay content and the air drying period have an impact on the CBR. The amount of water present in the soil has no significant effect on the CBR when it has $100 \%$ sand $(0 \%$ kaolin clay content), since CBR values will remain at around $15-20 \%$ irrespective of the amount of water present [10]. When the amount of kaolin in a specimen is increased up to $5 \%$, the CBR will decrease under both soaked and un-soaked conditions. However, it can result in a slight increase in the CBR when the specimens are dried for 1 or 2.5 days. A significant increase in the CBR is shown when a specimen with 10\% kaolin clay content was dried (a 90:10 mixture). A 90:10 mixture has the best proportion in relation to CBR (even though according to compaction curves, the highest MDD resulted from 80:20 mixtures). The CBR of a 90:10 mixture increases from $18.6 \%$ in a soaked condition to $28.3 \%$ in an un-soaked condition. The CBR increases to $41.3 \%$ and $48.5 \%$, when the sample is dried for 1 and 2.5 days respectively. When the kaolin clay percentage is increased beyond $10 \%$, the CBR will decrease even when the samples are airdried.

\subsubsection{Correlation with Fine Content}

The changes in the CBR with a fine content of Lateritic soil have been studied under two conditions namely, soaked and un-soaked. The previous study was able to develop the correlations. The results indicated that both unsoaked CBR (CBRu) and soaked CBR (CBRs) decrease with the increase of the fine content of all the samples tested. The CBR and the fine content exhibit a polynomial relationship of third order with a coefficient of correlation of 0.910 [11]

A relationship between the $C B R$ and the fine content of soil could be further established through the relationship that exists between the CBR and the amount of soil passing through the No. 200 sieve and also through the relationship between the $\mathrm{CBR}$ and the amount of soil passing through the No. 4 sieve. It has been revealed using fitted models that the coefficients of correlation were low. The R2 values obtained for the No. 200 sieve and the No. 4 sieve are 0.4409 and 0.3452 respectively [13].

\section{- DCP Index}

The Dynamic Cone Penetrometer Index (DCPI) is the most versatile rapid in situ evaluation device currently available for determining subgrade properties. The CBR was determined using the Dynamic Cone Penetration Index and a relationship established.

It is observed that with the increase of the percentage of fines, the CBR percentage increases. It may be due to the increased affinity to water molecules that takes place when the amount of fines is increased. When the percentage of fines is increased from $21.81 \%$ to $52.41 \%$, the CBR also increases from $2.62 \%$ to $4.15 \%$ [12]. 


\subsubsection{Correlation with the Maximum Dry Density}

A model has been developed to observe the changes in CBR when the maximum dry density is changed. For this model, the correlation coefficient was 0.54 . Equation 2 has been developed to assess the value of CBR using the change of fine fraction and MDD.

$$
\begin{gathered}
C B R=0.025(P 200)^{4}+30.13(\mathrm{MDD}) \\
-25.813
\end{gathered}
$$

where

CBR - Soaked California Bearing Ratio, \% P200 - Percentage of particles passing through the U.S .No. 200 sieve MDD - Maximum Dry Density according to Modified Proctor Method, $\left(t / \mathrm{m}^{3}\right)$

This model has an $\mathrm{R}^{2}$ of $0.785, \mathrm{R}^{2}$ adj of 0.776 , and the ratio between the standard error of estimate and the standard deviation is 0.463 [13].

\subsubsection{Correlation with the Plasticity Index}

Equation 3 has been developed for soils in soil groups such as $\mathrm{GM}, \mathrm{GC}, \mathrm{SM}, \mathrm{SC}, \mathrm{ML}, \mathrm{MH}, \mathrm{CL}$, and $\mathrm{CH}$ of the Unified Soil Classification System which contain over $12 \%$ of fines and exhibit a certain degree of plasticity [14].

The suggested equation is:

$C B R=75 /[1+0.728(\# 200)(P I)$

where

\#200 - Percentage of particles passing U.S. No. 200 Sieve

PI - Plasticity Index

There have been recent studies which have determined for fine-grained soil, the correlation between the MDD and the CBR as well as the correlation between the Plasticity Index and the CBR. Modes of plasticity index vs. CBR for experimental soil samples at OMC were obtained with a correlation coefficient of 0.34 . The maximum dry density vs. CBR for the experimental soil samples at OMC also gives a $\mathrm{R}^{2}$ of 0.27 [15].

Stabilized soils with only very fine cracks, and crushed stone or gravel with more than 15 percent of material finer than the 75 micron sieve are themselves impermeable having a permeability below $10^{-7}$ meters per second. Therefore, sub-grades under road pavements which include these materials are unlikely to be influenced by water infiltrating directly from the top. In instances where the sub-grade itself is permeable and can drain freely, it is advisable to not to impede vertical drainage. If this becomes possible by ensuring that each layer of the pavement is more permeable than the layer above it, then an additional drainage layer through the shoulders will not be required [16].

\subsection{Sub-base Construction Practices in Sri Lanka \\ 3.4.1 SSCM 2002}

Materials used for the soil sub-base shall have naturally occurred, or shall be blended gravels and sands, or mixtures thereof, and shall not include highly plastic clays, silts, peat, or other organic soils, or any soil that is contaminated with top soil, vegetable, and other deleterious matter. The material used for the top $150 \mathrm{~mm}$ of sub-base shall conform to the requirements of Type I material and the material used for the lower layers of sub-base shall conform to the requirements of Type II material.

Type I Sub-base Material: The CBR of the soil under 4-day soaked conditions when compacted to $100 \%$ maximum dry density under standard conditions of compaction shall not be less than $20 \%$. The PI and LL of the soil shall be less than $15 \%$ and $40 \%$ respectively. This condition may however be relaxed at the discretion of the engineer when the portion of material finer than $75 \mu \mathrm{m}$ is small.

Type II Sub-base Material: The CBR of the soil under 4-day soaked conditions when compacted to $100 \%$ maximum dry density under standard conditions of compaction shall not be less than $8 \%$. The PI and LL of the soil shall be less than $15 \%$ and $40 \%$ respectively. This condition may however be relaxed at the discretion of the engineer if the portion of material finer than $75 \mu \mathrm{m}$ is small [2].

\subsubsection{SSCM 2009}

Soil for Upper Sub-base: Materials used for the upper sub-base shall have naturally occurred or shall be blended gravels, and sands or mixtures thereof, and shall not include highly plastic clays, peat, or other organic soils, or any soil that is contaminated with top soil, vegetable, and other deleterious matter. The completed upper sub-base shall contain no aggregate having a maximum dimension exceeding two thirds of the thickness of the compacted layer. The 4-day soaked CBR of the soil when compacted to $98 \%$ maximum dry density under modified conditions of compaction shall not be less than $30 \%$. The maximum dry density under 
modified conditions of compaction shall not be less than $1.750 \mathrm{~kg} / \mathrm{m}^{3}$. The PI and LL of the soil shall be less than $15 \%$ and $40 \%$ respectively. The grading requirement shall conform to Table 3.2 of SSCM 2009.

Soil for Lower Sub-base: Materials used for the lower sub-base shall have naturally occurred or shall be blended gravels, and sands or mixtures thereof, and shall not include highly plastic clays, peat, or other organic soils or any soil that is contaminated with top soil, vegetable, and other deleterious matter. The 4-day soaked CBR of the soil when compacted to $95 \%$ maximum dry density under modified conditions of compaction shall not be less than $15 \%$. The maximum dry density under modified conditions of compaction shall not be less than $1.650 \mathrm{~kg} / \mathrm{m}^{3}$. The PI and LL of the soil shall be less than $15 \%$ and $40 \%$ respectively [1].For the lower sub-base, the grading requirement has not been specified.

\subsubsection{Quality Control}

When quality controlling, the requirements given in Table 1 and Table 2 have to be satisfied for upper sub-base materials:

Table 1 - Requirements for the Upper Subbase of Flexible Pavements

\begin{tabular}{|l|l|c|}
\hline \multicolumn{1}{|c|}{ Property } & $\begin{array}{c}\text { Test } \\
\text { Method } \\
\text { (AASHTO) }\end{array}$ & $\begin{array}{c}\text { Upper Sub } \\
\text { Base }\end{array}$ \\
\hline Liquid Limit(LL) & T-89 & $\begin{array}{c}\text { Not to } \\
\text { exceed } 40 \%\end{array}$ \\
\hline $\begin{array}{l}\text { Plasticity Index } \\
\text { (PI) }\end{array}$ & T-90 & $\begin{array}{c}\text { Not to } \\
\text { exceed 15\% }\end{array}$ \\
\hline $\begin{array}{l}\text { Maximum Dry } \\
\text { Density } \\
\text { (Modified) }\end{array}$ & T-180 & $\begin{array}{c}\text { Not less } \\
\text { than } \\
1,750 \mathrm{~kg} / \mathrm{m} 3\end{array}$ \\
\hline $\begin{array}{l}\text { 4-day soaked } \\
\text { CBR at 98\% MDD } \\
\text { (Modified) }\end{array}$ & $\mathrm{T}-193$ & $\begin{array}{c}\text { Not less } \\
\text { than 30\% }\end{array}$ \\
\hline
\end{tabular}

Table 2 - Grading Requirements for the Upper Sub-base

\begin{tabular}{|c|c|c|}
\hline \multicolumn{2}{|c|}{ Sieve Size } & Percentage by weight \\
\hline $\mathbf{m m}$ & $\boldsymbol{\mu m}$ & Passing sieve \\
\hline 50 & & 100 \\
\hline 37.5 & & $80-100$ \\
\hline 20 & & $60-100$ \\
\hline 5 & & $30-100$ \\
\hline 1.18 & & $17-75$ \\
\hline & 300 & $9-50$ \\
\hline & 75 & $5-25$ \\
\hline
\end{tabular}

- Liquid Limit Test (LL Test) has to be conducted in accordance with AASHTO specifications [17].

- Plastic Limit Test (PL Test) has to be conducted in accordance with AASHTO specifications [18].

- Maximum Dry Density at which an excellent compaction of soil occurs when the soil achieves the optimum moisture content and maximum dry density [19] has to be in accordance with AASHTO specifications [20].

- California Bearing Ratio Test (CBR) and Sieve Analysis Test have to be conducted [1].

\subsection{Research Need}

Most roads in Sri Lanka have been constructed to fulfill the requirements stipulated in the standard specifications. It is noted that until such time that the second edition was published, the grading was not considered in selecting materials for the construction of the sub-base. The maximum dry density of the material was also not considered.

It is difficult to find sub-base materials that satisfy the specifications given in SSCM 2009. The difficulties encountered in satisfying the required properties vary according to the area concerned. Even though LL, PI, MDD, CBR, and sieve analysis results have to satisfy the SSCM 2009 requirements, only LL, PI, and CBR values given in SSCM 2002 have been considered in selecting sub-base materials and some projects in the country still work according to SSCM 2002.

Therefore, it is essential to find out the importance of the properties of these materials and whether any relaxation is possible. Furthermore, it is important to ascertain any possible relationships among the properties.

The objectives of the research are therefore as follows:

- To investigate the effect of the fine percentage on properties of sub-base material.

- To find out the significant correlations between properties of sub-base material and the fine particle fraction of a selected sample.

- To investigate the proper method of relaxation for the materials in marginal values of the grading band (fine fraction) to be used as sub-base materials in construction work. 


\section{Methodology}

\subsection{Questionnaire Survey}

A questionnaire survey was conducted among experienced professional engineers who have worked in the road sector for over fifteen years. The objective was to verify the methods of material selection, the importance of the properties required of the material, and the performance of already constructed roads as per different specifications.

\subsection{Sampling Method}

It is a difficult task to find suitable sub-base materials with varied percentages of fines. Therefore, it was decided to prepare soil samples that satisfy all sub-base material requirements specified in the SSCM by initially blending two types of soil.

Sieve analysis, CBR, MDD, OMC, LL, and PI values were obtained for this sub-base material. A stock of fine particles was prepared by sieving soil through a $425 \mu \mathrm{m}$ sieve. These sieved fines were incrementally added to the prepared sub-base material to make ten different soil samples. Different types of soils were used in the blending trials until a suitable sub-base material was formed.

Properties and the particle size distributions of the two soil types (Type 1 and Type 2) which were used for blending are shown in Table 3 and Table 4 respectively. The blended soil sample had $32 \%$ of LL, $7 \%$ of PI, $8.5 \%$ of OMC, $2.04 \mathrm{~kg} / \mathrm{m}^{3}$ of MDD and $59 \%$ of CBR. The particle size distribution of the blended sample is illustrated in Figure 1 with the specified grading bands.

Table 3 - Properties of Blending Soils

\begin{tabular}{|l|l|l|l|l|l|}
\hline $\begin{array}{l}\text { Soil } \\
\text { Type }\end{array}$ & $\begin{array}{l}\text { LL } \\
\%\end{array}$ & $\begin{array}{l}\text { PI } \\
\%\end{array}$ & $\begin{array}{l}\text { OMC } \\
\%\end{array}$ & $\begin{array}{l}\text { MDD } \\
\left(\mathbf{k g} / \mathbf{m}^{3}\right)\end{array}$ & $\begin{array}{l}\text { CBR \% } \\
\text { Soaked }\end{array}$ \\
\hline 1 & NP & NP & 9 & 2.090 & 46 \\
\hline 2 & 33 & 8 & 15.5 & 1.705 & 14 \\
\hline
\end{tabular}

Table 4 - Properties of Blending Soils

\begin{tabular}{|l|l|l|l|}
\hline \multirow{2}{*}{$\begin{array}{c}\text { Sieve } \\
\text { Size } \\
(\mathbf{m m})\end{array}$} & \multicolumn{2}{|c|}{ \% Passing } & \multirow{2}{*}{ Spec. Limits } \\
\cline { 2 - 3 } & Type 1 & Type 2 & \begin{tabular}{l} 
Table 1708-3 \\
\hline 50
\end{tabular} \\
\hline 37.5 & 100 & 100 & 100 \\
\hline 20 & 98.9 & 95.2 & $60-100$ \\
\hline 5 & 81 & 73 & $30-100$ \\
\hline 1.18 & 48.7 & 27.5 & $17-75$ \\
\hline 0.3 & 34.9 & 7.5 & $9-50$ \\
\hline 0.075 & 32.7 & 1.8 & $5-25$ \\
\hline
\end{tabular}

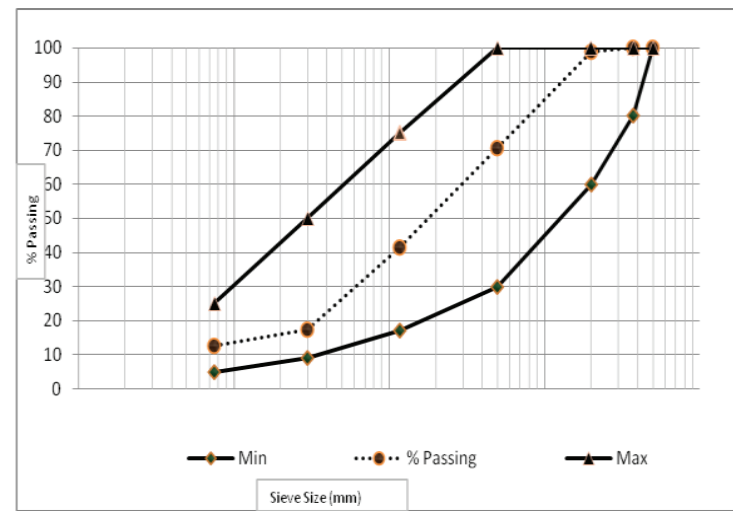

Figure 1 - Particle Size Distribution of the Blended Sample

It was decided to find out the changes in the properties of this blended sub-base (50:50 blends of Type 1 and Type 2) by varying the fine fraction. A heap of fine material was prepared by sieving Type 2 soil through a 425 $\mu \mathrm{m}$ sieve. Volume batching was used in sample preparation. Table 5 shows the volume proportion of the sub-base and the volume of fine passing a $425 \mu \mathrm{m}$ sieve.

Table 5 - Blending Proportion of the Samples

\begin{tabular}{|c|c|c|}
\hline $\begin{array}{c}\text { Sample } \\
\text { No }\end{array}$ & $\begin{array}{c}\text { Sub-base Material } \\
\text { (Number of }_{\text {units) }}^{*}\end{array}$ & $\begin{array}{c}\mathbf{0 . 4 2 5} \mathbf{~ m m} \\
\text { passing, } \mathbf{c m}^{3}\end{array}$ \\
\hline 1 & 1 & 0 \\
\hline 2 & 2 & 50 \\
\hline 3 & 2 & 150 \\
\hline 4 & 2 & 250 \\
\hline 5 & 2 & 300 \\
\hline 6 & 2 & 400 \\
\hline 7 & 2 & 500 \\
\hline 8 & 2 & 600 \\
\hline 9 & 2 & 750 \\
\hline 10 & 2 & 900 \\
\hline
\end{tabular}

${ }^{*}$ Note: 1 Unit $=1000 \mathrm{~cm}^{3}$ 
- Sieve Analysis - AASHTO T88-00 [21].

- Atterberg Limit Tests - AASHTO T8910 and T90-00 [17, 18].

- CBR Test - AASHTO T193-99 [22].

- MDD and OMC Tests- AASHTO T18010 [20].

Atterberg limit tests were only performed with Sample numbers 1, 4, and 7 in order to confirm soil uniformity since the Atterberg limit has to be unique for all samples having fine fractions separated from Type 2 soil. Variations of sieve passing along with the specified grading band are shown in Figure 2.

However, during $300 \mu \mathrm{m}$ sieve passing, only the value of Sample 10 exceeded the maximum allowable passing limit of $50 \%$. Table 6 illustrates the passing percentages through 425 $\mu \mathrm{m}, 300 \mu \mathrm{m}$ and $75 \mu \mathrm{m}$ sieves and MDD, OMC, and CBR values of the 10 samples. The MDD values of all samples were each greater than the minimum requirement of $1.75 \mathrm{~kg} / \mathrm{m}^{3}$.

The CBR variation with reference to sieve passing through a $425 \mu \mathrm{m}$ sieve, $300 \mu \mathrm{m}$ sieve and $75 \mu \mathrm{m}$ sieve is shown in Figure 3. The MDD variation with reference to sieve passing through a $425 \mu \mathrm{m}$ sieve, $300 \mu \mathrm{m}$ sieve and a 75 $\mu \mathrm{m}$ sieve is shown in Figure 4. Figure 5 shows the OMC change according to sieve passing through a $425 \mu \mathrm{m}$ sieve, $300 \mu \mathrm{m}$ sieve and a 75 $\mu \mathrm{m}$ sieve.

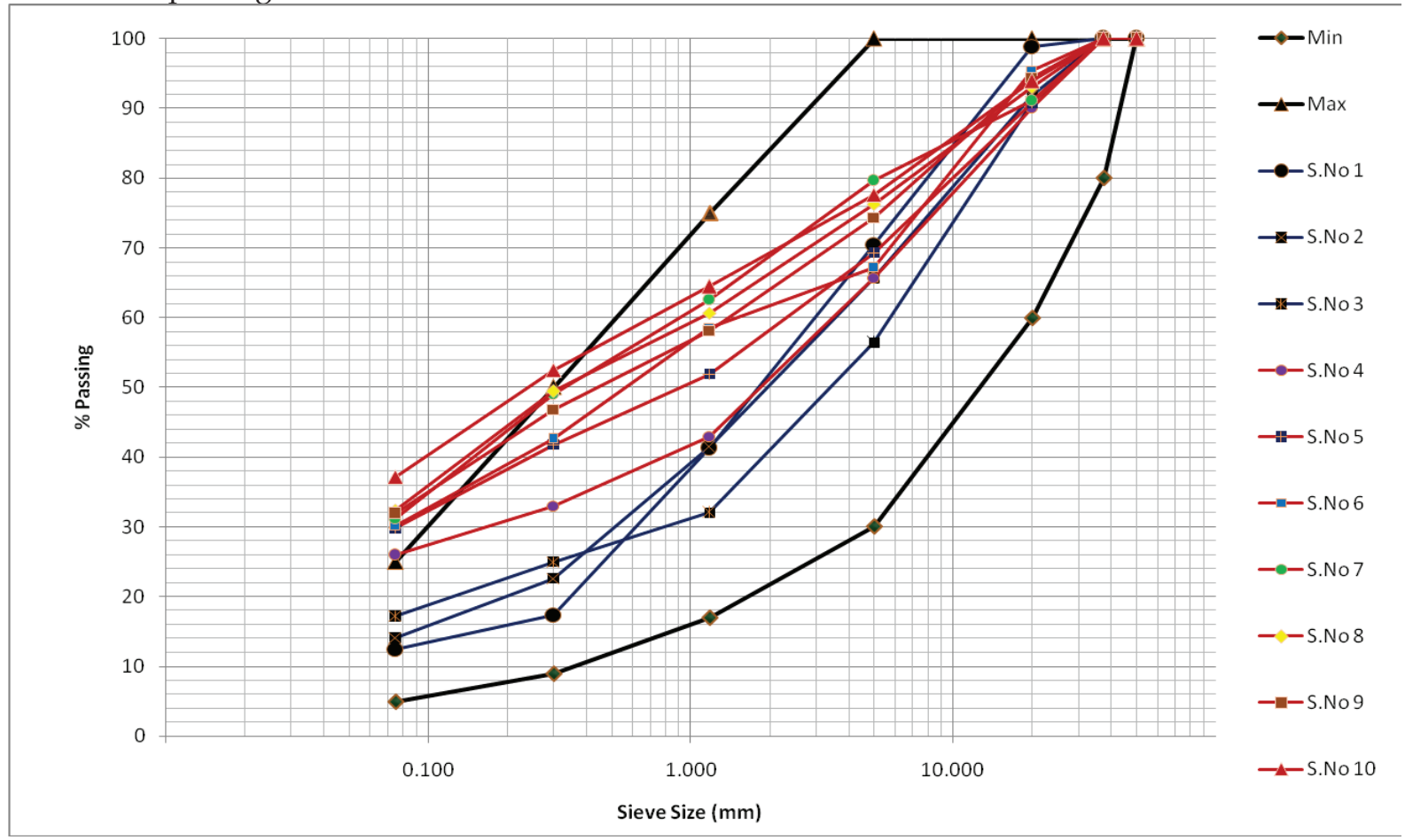

Figure 2 - Particle Size Distribution Variation of Blended Samples

Table 6 - Material Properties of Soil Samples

\begin{tabular}{|c|c|c|c|c|c|c|}
\hline $\begin{array}{c}\text { Sample } \\
\text { No. }\end{array}$ & $\begin{array}{c}\mathbf{0 . 4 2 5} \text { sieve } \\
\text { (\% passing) }\end{array}$ & $\begin{array}{c}\mathbf{0 . 3 0 0} \text { sieve } \\
\text { (\% Passing) }\end{array}$ & $\begin{array}{c}\mathbf{0 . 0 7 5} \text { sieve } \\
\text { (\% passing) }\end{array}$ & $\begin{array}{c}\text { MDD } \\
\left(\mathbf{k g} / \mathbf{m}^{3}\right)\end{array}$ & $\begin{array}{c}\text { OMC } \\
\mathbf{( \% )}\end{array}$ & $\begin{array}{c}\text { CBR 98\% at MDD\& } \\
\text { OMC (\%) }\end{array}$ \\
\hline 1 & 22.8 & 17.4 & 12.5 & 2.040 & 8.5 & 59 \\
\hline 2 & 24.6 & 22.6 & 14.1 & 2.043 & 8.6 & 58 \\
\hline 3 & 27.5 & 25.0 & 17.2 & 2.025 & 8.9 & 52 \\
\hline 4 & 35.2 & 33.0 & 25.9 & 1.980 & 9.7 & 49 \\
\hline 5 & 45.0 & 41.8 & 29.8 & 1.977 & 9.9 & 44 \\
\hline 6 & 49.7 & 42.6 & 30.1 & 1.959 & 10.3 & 40 \\
\hline 7 & 54.5 & 49.0 & 31.2 & 1.972 & 11.1 & 38 \\
\hline 8 & 54.3 & 49.4 & 32.4 & 1.952 & 11.6 & 37 \\
\hline 9 & 55.1 & 46.8 & 31.9 & 1.940 & 11.8 & 30 \\
\hline 10 & 59.3 & 52.5 & 37.2 & 1.917 & 12.2 & 25 \\
\hline
\end{tabular}




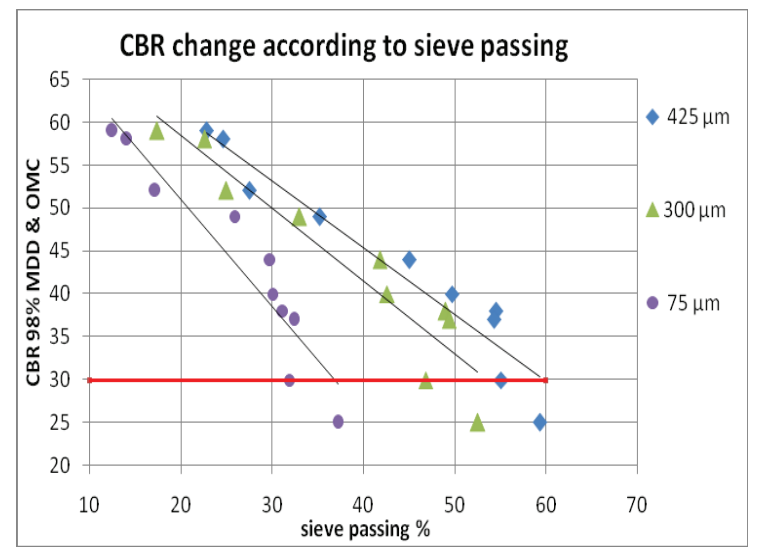

Figure 3 - Variation of CBR with \% passing

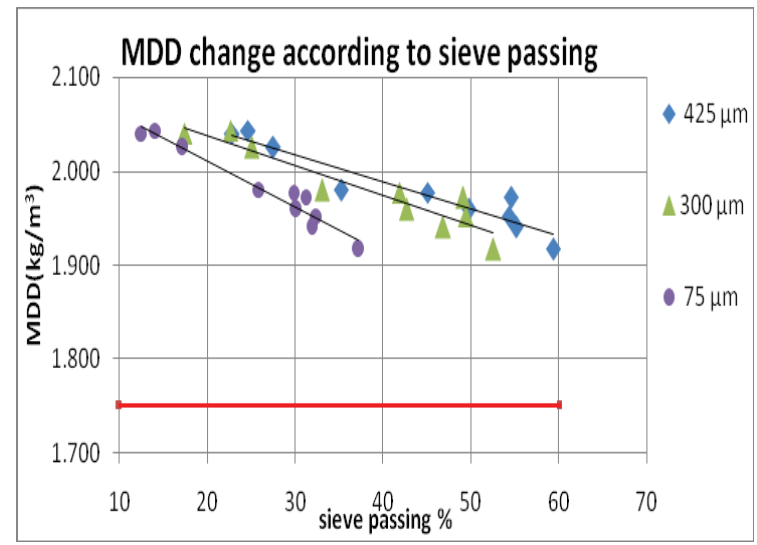

Figure 4 - Variation of MDD with \% passing

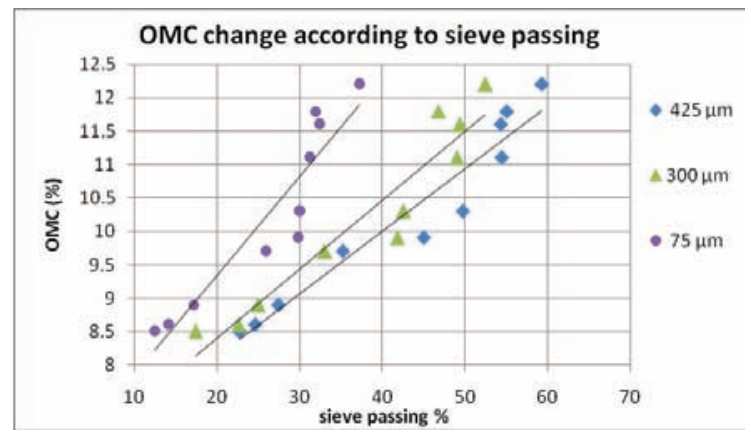

Figure 5 - Variation of OMC with \% passing

\section{Results and Discussion}

5.1 Summary of the Questionnaire Survey Approximately $49 \%$ of the engineers either "strongly agreed or agreed" that finding subbase material according to SSCM 2009 is extremely difficult. About $65 \%$ of the respondents identified $\mathrm{CBR}$ as the most important factor to be considered in material selection and $84 \%$ said that were of the view that there should be less importance given to grading. According to $51 \%$ of the respondents, PI is the parameter that is most difficult to be satisfied.
However, according to $16 \%$ of the respondents, grading is the most difficult parameter. Nearly $67 \%$ recommended relaxing the grading. Around 93\% agreed with the limits given in SSCM 2009. Nine percent (9\%) of the engineers proposed that shrinkage should be included in specifications as an additional property. Almost $35 \%$ of the respondents agreed that they have used marginal or substandard material in their road construction projects [23].

\subsection{Soil Classification}

Samples 1 to 9, according to AASHTO classification, come under the group A-2-4, which is generally rated as 'excellent to good' and Sample 10 comes under A-4 which is generally rated as 'fair to poor'. The same result is represented in the test summary, where the CBR value (25) of Sample 10 is less than the minimum requirement (30) when the percentage passing the No.200 sieve is more than $35 \%$.

The Group Index (GI) values of all samples were 0 . As per the USCS classification, the group symbol of Sample number 3 was GM and that of each of the others was SM. It was revealed that four-day soaked swell percentages for moulds prepared by 10, 30, and 65 blows were very much less than $2 \%$.

\subsection{Correlations of Material Properties}

The changes of the CBR when different fractions passed through the $425 \mu \mathrm{m}, 300 \mu \mathrm{m}$, and $75 \mu \mathrm{m}$ sieves were found. In the fitted models, the fine content of the material affected their CBR values. The CBR of the material decreased as the fine content was increased. However, it can be noted that the selected samples, which were outside the grading band recommended by the SSCM, satisfied the CBR requirements specified in the SSCM. The correlation coefficient $\left(\mathrm{R}^{2}\right)$ of the fitted models was 0.926 for a $425 \mu \mathrm{m}$ sieve passing, 0.890 for a $300 \mu \mathrm{m}$ sieve passing and 0.889 for a $75 \mu \mathrm{m}$ sieve passing.

\subsubsection{MDD vs \% Passing}

The MDD values of the material decreased with the increase of the fine content. Nevertheless, it is notable that the selected samples which were outside the grading band recommended by the SSCM satisfy the MDD requirement specified in the SSCM. The correlation coefficient $\left(\mathrm{R}^{2}\right)$ of the fitted models were 0.905 for a $425 \mu \mathrm{m}$ sieve passing, 0.888 for a $300 \mu \mathrm{m}$ sieve passing, and 0.952 for a $75 \mu \mathrm{m}$ sieve passing. 


\subsubsection{OMC vs \% Passing}

The OMC values of the material increased with the increase of the fine content. The correlation coefficient $\left(R^{2}\right)$ of the fitted models were 0.930 for a $425 \mu \mathrm{m}$ sieve passing, 0.904 for a $300 \mu \mathrm{m}$ sieve passing, and 0.868 for a $75 \mu \mathrm{m}$ sieve passing.

\subsubsection{Correlation of CBR vs MDD}

The CBR values of the material increased with the increase of the MDD value. The correlation coefficient $\left(\mathrm{R}^{2}\right)$ of the fitted model was 0.936 as shown in Figure 6. Thus the fitted model is found to be significant.

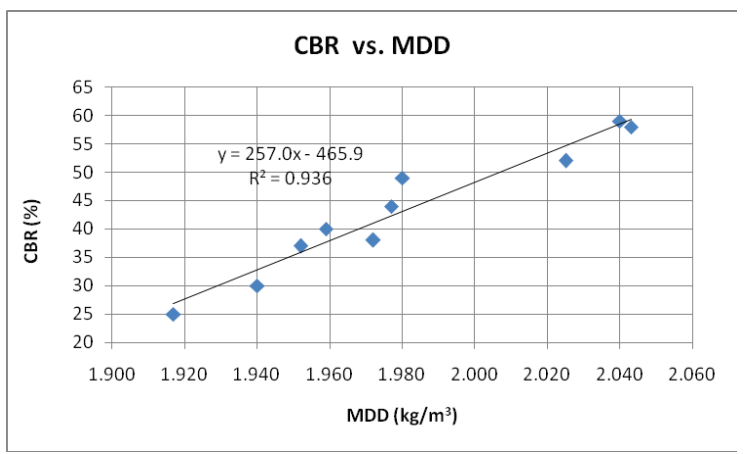

Figure 6 - Correlation of CBR to MDD

\subsubsection{Correlation of CBR vs OMC}

The CBR values of the material decreased with the increase of the OMC value. The correlation coefficient $\left(\mathrm{R}^{2}\right)$ of the fitted model was 0.953 as shown in Figure 7. Hence the fitted model is significant.

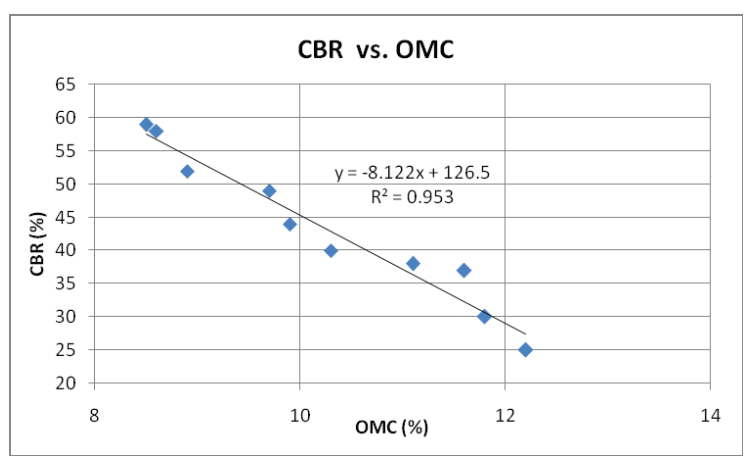

Figure 7 - Correlation of CBR to OMC

\subsubsection{Correlation of MDD vs OMC}

The MDD values of the material decreased with the increase of the OMC value. The correlation coefficient $\left(R^{2}\right)$ of the fitted model was 0.902 as shown in Figure 8. Thus the fitted model is significant.

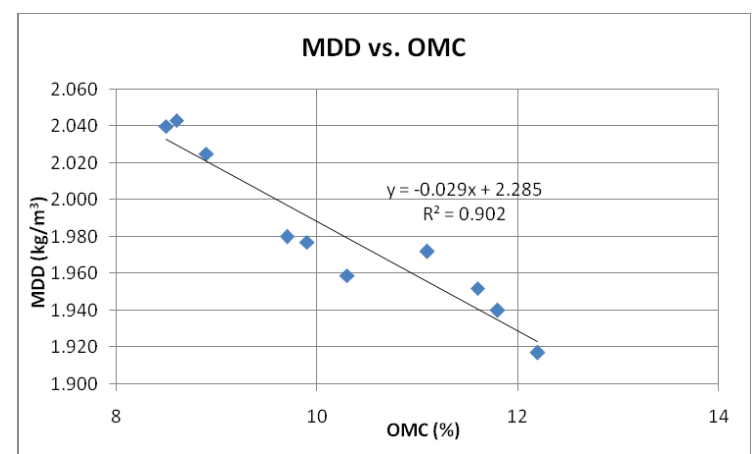

Figure 8 - Correlation of MDD to OMC

\subsection{Multivariate Effect of the Fine Fraction on CBR}

The stepwise multivariate regression analysis was done considering fine fractions. Two scenarios were considered as given in Equations 4 and 5.

CBR

$=77.295$

$-1.308(425 \mu \mathrm{m}$ passing \& $300 \mu \mathrm{m}$ retaining)

$-0.258(300 \mu \mathrm{m}$ passing $\& 75 \mu \mathrm{m}$ retaining)

-0.945 (75 $\mu \mathrm{m}$ passing)

where

Correlation of Coefficient $\left(R^{2}\right)$ is 0.942

CBR

$=76.062$

$-0.448(300 \mu \mathrm{m}$ passing \& $75 \mu \mathrm{m}$ retain $)$

$-1.051(75 \mu \mathrm{m}$ passing $)$

where

Correlation of Coefficient $\left(R^{2}\right)$ is 0.898

Equation 5 was used to predict the CBR values of the 40 soil samples whose LL, PI, MDD, and CBR values satisfied the sub-base requirements. However, none of the predicted CBR values were close to the actual CBR values. Therefore, it is confirmed that the models, Equation 4, and Equation 5 only represent the soil used for this experiment.

\section{Conclusion}

The study revealed that the fine fraction of a selected material affects the CBR and MDD values of the material. When the fine fraction increases, $\mathrm{CBR}$ and MDD values of the soil decrease. In addition, the optimum moisture content increases as the fine fraction of the material increases. The fitted models for CBR, MDD, and OMC expressed a significant relationship with the selected variables with the correlation coefficients for these models being higher than 0.80 . A significant linear relationship exists between the CBR and MDD 
with the higher $\mathrm{R}^{2}$ value. Since CBR and OMC change with the fine fraction of the soil, a linear relationship could be expected between the CBR and OMC with a higher $\mathrm{R}^{2}$ of 0.953 .

The linear regression models developed to predict the CBR showed high correlation coefficients with the independent variables of the percentages passing through different sieve sizes ( $\mathrm{R}^{2}$ of 0.942 and 0.898 for Equation 4 and Equation 5 respectively). Statistical analysis revealed that percentages of the material passing through the $425 \mu \mathrm{m}$ sieve but retained on $300 \mu \mathrm{m}$ and $75 \mu \mathrm{m}$ sieves are the significant parameters when predicting the CBR of the selected soil in this study. These models help to estimate the CBR value through sieve analysis results and comparing them with the laboratory CBR value of the tested material. However, the regression equations developed are only applicable for the soil used in this study. This may be the reason for $\mathrm{R}^{2}$ values higher than those obtained in previous studies done for soils in general.

It can be recommended that the grading band of No.200 sieve passing can be relaxed up to $35 \%$, if the soil sample satisfies the specified CBR requirement (30) and also if the PI value is less than or equal to 10, and if the swell percentage is less than $2 \%$. Further studies will be required to revise the present grading band by extending this research to different types of soils found in Sri Lanka.

\section{References}

1. Institute for Construction Training and Development (ICTAD) (2009). Standard Specification for Construction and Maintenance of Road and Bridges (SSCM), 2nded.

2. Institute for Construction Training and Development (ICTAD) (2002). Standard Specification for Construction and Maintenance of Road and Bridges (SSCM), 1sted.

3. Lay, M. G., (2009).Handbook of Road Technology. $4^{\text {th }}$ edition. chapter.8, Spon Press: London and New York.

4. Ingles, O. G, and Metcalf, J. B., (1972). Soil stabilization: principles and practices. Butterworths: Sydney.

5. Holland, J. E., and Richards, J., (1982). Road pavements on expansive clays. Australian Road Research, volume. 12(3), pp. 173-179.
6. Nicholas, J. Garber and Lester, A. Hoel (2009). Traffic and Highway Engineering,. $4^{\text {th }}$ Edition. Chapter 17, Cengage Learning.

7. The American Association of State Highway and Transportation Officials (AASHTO) (2007). Standard Specifications for Transportation Materials and Methods of Sampling and Testing, 27th edition. The American Association of State Highway and Transportation Officials Washington, D.C., USA.

8. American Society for Testing and Materials (ASTM) (2002). The Unified Soil Classification System, Annual Book of ASTM Standards, volume. 4.08, American Society for Testing and Materials, West Conshohocken, PA.

9. Liu, T. K. (1970). A Review of Engineering Soil Classification Systems Special Procedures for Testing Soil and Rock for Engineering Purposes.5 th edition, ASTM Special Technical Publication 479, American Society for Testing and Materials, Easton, MD.

10. Purwana, Y. M., Nikraz, H., and Jitsangiam, P., (2012). Experimental Study of Suction-Monitored CBR Test on Sand-Kaolin Clay Mixture. International Journal of GEOMATE, vol. 3(2) (SI. No. 6), pp. 419-422.

11. Ayodele, A.L., Falade, F. A., and Ogedengbe, M. O., (2009). Effect of fines on some engineering properties of lateritic soil in Ile-Ilf, Nigeria. Journal of Engineering Research, vol. 9(32), pp. 1-16.

12. DeepikaChukka, and Chakravarthi, V. K., (2012). Evaluation of Properties of Soil Subgrade Using Dynamic Cone Penetration Index-A Case Study. International Journal of Engineering Research and Development .e-ISSN: 2278-067X, p-ISSN: 2278800X, Available: www.ijerd.com, vol. 4(4), pp. 715.

13. Samar A. Taha, Sherif M. El-Badawy, and Alaa M. Ali (2014). Determination of California Bearing Ratio through Material Index Properties, The Fourth Jordan International Conference and Exhibition for Roads and Transport: High Priority Issues in the Future Transport Sector, pp. 16-20.

14. National Cooperative Highway Research Program (2001). Guide for Mechanistic-Empirical Design of new and rehabilitated pavement structures, Appendix CC-1: Correlation of CBR values with soil index properties, National Cooperative Highway Research Program, Transportation Research Board, National Research Council.

15. BaoThachNguyen, and Abbas Mohajerani (2015). Prediction of California Bearing Ratio from Physical Properties of Fine-Grained Soils. World Academy of Science, Engineering and Technology International Journal of Civil, Structural, Construction and Architectural Engineering, vol. 9(2), pp. 136-141. 
16. Overseas development Administration, Overseas Road Note 31 (1993). $4^{\text {th }}$ edition, A guide to the structural design of bitumen surfaced roads in tropical and sub tropical countries. Overseas centre, Transport Research Laboratory, Crowthrone, Berkshire, United Kingdom.

17. American Association of State Highway and Transportation Officials (2001). Determining the Liquid Limit of Soils, AASHTO Designation: T 8910.

18. American Association of State Highway and Transportation Officials (2008). Determining the Liquid Limit of Soils, AASHTO Designation: T 9000 .

19. Proctor, R. R., (1933). "Fundamental Principal of Soil Compaction". Engineering News-Record, Vol.3 (9).
20. American Association of State Highway and Transportation Officials (2010). Moisture Density Relations of Soils Using a 4.54-kg (10-lb) Rammer and a 457-mm (18-in.) Drop, AASHTO Designation: T 180-10.

21. American Association of State Highway and Transportation Officials (1996). Particle Size Analysis of Soils, AASHTO Designation: T 88-93.

22. American Association of State Highway and Transportation Officials (2003). The California Bearing Ratio, AASHTO Designation: T 193-99.

23. Inan, I. I. I., (2015). Effect of fine percentage on properties of sub-base material, Department of Civil Engineering, University of Moratuwa. 